\title{
Pengaruh Gaya Kepemimpinan Transformasional, Kepuasan Kerja Dan Motivasi Terhadap Kinerja Pegawai Bank NTB Syariah Pada Kantor Cabang Bima
}

\author{
Rahmatul Irfan \\ Program Pascasarjana Universitas Terbuka \\ Email: rahmatu12000@gmail.com
}

\begin{abstract}
Abstrak. Maju mundurnya suatu organisasi sangat ditentukan oleh kinerja anggota sebagai sumber daya utama dalam organisasi sehingga tujuan organisasi dapat tercapai sesuai target yang telah ditetapkan, termasuk organisasi perbankan syariah yang berbasis pada Al-Quran dan AlSunnah sebagai landasan dasar hukum dan operasionalnya. Perbankan syariah merupakan fenomena baru dalam dunia ekonomi modern dan diyakini sebagai solusi atas keterpurukan tatanan kesejahteraan ekonomi masyarakat terutama masalah keadilan sosial ekonomi. Penelitian bertujuan untuk menganalisis gaya kepemimpinan, motivasi kerja dan kepuasan kerja terhadap kinerja pegawai Bank NTB Syariah Pada Kantor Cabang Bima dengan polulasi pegawai Bank Syariah Cabang Bima. Jumlah sampel penelitian sebanyak 54 orang. Penentuan sampel ini menggunakan non-probabilitas karena hanya pegawai yang memiliki kriteria tertentu yang dijadikan sebagai sampel penelitian. Untuk mengumpulkan data variabel penelitian menggunakan instrumen penelitian berupa kuesioner dengan menggunakan skala likert. Data dianalisis dengan menggunakan analisis regresi linier berganda. Adapun hasil analisis regresi linier berganda diketahui bahwa gaya kepemimpinan transformasional, kepuasan kerja dan motivasi kerja baik secara parsial maupun secara simultan berpengaruh signifikan dan positif terhadap kinerja pegawai. Oleh karena itu penting bagi pimpinan untuk melakukan berbagai upaya motivasi dan meningkatkan kepuasan kerja pegawai agar dapat meningkatkan kualitas kerja.
\end{abstract}

Kata Kunci: Gaya Kepemimpinan, Kepuasan Kerja, Motivasi, Kinerja.

\section{PENDAHULUAN}

Kemunculan perbankan syariah atau perbankan Islam selama ini dengan sistem ekonomi syariah dan seiring dengan adanya upaya dari sarjana Muslim yang mendukung perkembangan gagasan ekonomi yang berbasis nilai-nilai Islam. Demikian di abad ini adalah sebuah gerakan ekonomi baru yang ikut mengadu gagasan dan konsep dengan perekonomian modern. Perekonomian Syariah lebih ditunjukkan penerapannya pada konsep ekonomi moneter melalui Bank Syariah dengan menjadi kitab suci agama Islam sebagai dasar hukum pelaksanaannya. Antara bank konvensional dengan Bank Syariah ditemukan perbedaan yang mendasar (hal-hal yang prinsip) terutama masalah bunga. Sebagaimana diketahui bank bahwa konvenional akrab dengan istilah bunga baik bunga pinjaman maupun bunga tabungan, sedangkan bank syariah menggunakan istilah bagi hasil karena bunga bank merupakan Jurnal Ilmu Sosial dan Pendidikan perbuatan yang tidak dibernarkan dalam syariat Islam. Dengan melihat fenomena demikian karena bunga bank merupakan perbuatan yang tidak sesuai dengan ajaran Islam maka munculah berbagi desakan dari kalangan ekonom Islam agar membangun jasa transaksi keuangan yang sejalan dengan syariah Islam. Hal ini membuat semakin hari popularitas perbankan syariah semakin digemari oleh kalangan Islam termasuk nonmuslim di belahan dunia. Pasar keuangan beberapa tahun terkahir ini menyadari bahwa perlu melakukan perubahan sistem moneter harus segera dievelauasi mengingat perbankan sebagai sektor non ril memegang peranan penting terhadap maju mundurnya suatu perekonomi modern. Perubahan sistem dilakukan dengan konseptualisasi sistem perbankan yang bersumber dari interpretasi terhadap konsep dasar Islam (Marimin dan Romdhoni, 2015:75). 
Bank Syariah pada awalnya dikembangkan sebagai suatu respon dari kelompok ekonomi dan praktisi perbankan muslim yang berupaya mengakomodasi desakan dari berbagai pihak yang menginginkan agar tersedia jasa transaksi keuangan yang dilaksanakan sejalan dengan nilai moral dan prinsip-prinsip syariah Islam. Umat Islam diharapkan dapat memahami perkembangan bank syariah dan mengembangkannya apabila dalam posisi sebagai pengelola bank syariah yang perlu secara cermat mengenali dan mengidentifikasi semua mitra kerja yang sudah ada maupun yang potensial untuk pengembangan bank syariah.

Ada tiga masalah besar di perbankan syariah. Ini yang menghambat perkembangan bisnis syariah sampai saat ini: Pertama, ketersediaan produk dan standarisasi produk perbankan syariah. Hal ini dikarenakan selama ini masih banyak bank syariah yang belum menjalankan bisnisnya sesuai prinsip syariah. Standarisasi ini diperlukan dengan alasan industri perbankan syariah memiliki perbedaan dengan bank konvensional. Apalagi, produk bank syariah tidak hanya diperuntukkan bagi nasabah muslim, melainkan juga nasabah nonmuslim. Kedua, tingkat pemahaman (awareness) produk bank syariah. Hingga saat ini, sangat sedikit masyarakat yang tahu tentang produk-produk perbankan syariah dan istilah-istilah di perbankan syariah. "Hanya sekitar 30 persen dari sumber daya yang direkrut mengetahui istilah perbankan syariah serta tingkat awareness-nya," Ketiga industri perbankan syariah adalah sumber daya manusia (SDM) (Kompas, 13/8/2012).

Provinsi Nusa Tenggara Barat (NTB) merubah konsep perbankan daerahnya dari Bank NTB Konvensional menjadi Bank NTB Syariah. Bank NTB Syariah adalah Bank milik Pemerintah Propinsi NTB bersamasama dengan Pemerintah Kota/Kabupaten seNTB. Demikian dilakukan berdasarkan Keputusan Rapat Umum Pemegang Saham tanggal 13 Juni 2016 yang menyetujui PT Bank NTB Syariah melaksanakan konversi menjadi Bank NTB Syariah sebagai harapan baru bagi penguatan ekonomi kerakyatan yang berkeadilan di Nusa Tenggara Barat. Proses konversi membutuhkan waktu selama dua tahun dan melahirkan Bank NTB Syariah resmi melakukan kegiatan operasional sesuai prinsip-prinsip syariah pada tanggal 24 September 2018. Tersebut dilakukan berdasarkan dengan Keputusan Anggota Dewan Komisioner Otoritas Jasa Keuangan (OJK) Nomor: Kep-145/D.03/2018 tentang Pemberian Izin Perubahan Kegiatan Usaha Bank Umum Konvensional menjadi Bank Umum Syariah PT Bank NTB Syariah menetapkan bahwa memberikan izin kepada PT Bank NTB Syariah yang berkedudukan di Kota Mataram untuk melakukan perubahan kegiatan usaha Bank Umum Konvensional menjadi Bank Umum Syariah dengan nama Bank NTB Syariah.

Didirikan dengan tujuan untuk dapat menjadi Bank Syariah yang amanah, terkemuka dan pilihan masyarakat, memberikan semangat lebih bagi Bank NTB Syariah untuk dapat terus menyediakan layanan perbankan syariah untuk membantu masyarakat dalam transaksi perbankan syariah serta meningkatkan perekonomian daerah di Nusa Tenggara Barat. Sebagaimana tercermin dalam visi Bank untuk menjadi Bank Syariah yang amanah, terkemuka dan pilihan masyarakat, kemudian visi ini akan diwujudkan oleh Bank dengan memberikan solusi keuangan yang menyeluruh kepada nasabah sehingga Bank dapat menjadi partner keuangan nasabah sepanjang masa, serta mencapai nilai tambah yang bermanfaat bagi seluruh stakeholder, yaitu nasabah, investor, karyawan, komunitas, dan industri keuangan.

Seiring dengan berjalannya waktu, Bank NTB Syariah terus berkembang hingga saat ini memiliki Kantor yang berjumlah 43 kantor yang terdiri dari 1 kantor pusat, 11 kantor cabang, 22 Kantor Cabang Pembantu, 4 Kantor Kas dan 5 Payment Point. Guna mendukung kualitas pelayanan Bank NTB Syariah 155 ATM yang tersebar diseluruh kota/Kabupaten se-NTB. Bank NTB Syariah didukung oleh karyawan dan karyawati sampai dengan 31 Maret 2018 berjumlah 740 orang. (Bank NTB Syariah, 2018). Peralihan 
status Bank NTB konvesional menjadi Bank NTB syariah tentunya akan berdapak pada berbagai aspek, termasuk pada kinerja Bank NTB itu sendiri. Menurut Mansyur (2012) bahwa salah satu aspek penting dalam pengukuran kinerja di dunia perbankan adalah efisiensi, dimana efisiensi dapat ditingkatkan melalui penurunan biaya (reducing cost) dalam proses produksi ataupun dengan meningkatkan pendapatan. Suatu perusahaan dikatakan memiliki tingkat efisiensi yang lebih tinggi jika dengan jumlah input tertentu dapat menghasilkan jumlah output lebih banyak atau pada jumlah output tertentu bisa menggunakan input lebih sedikit (Abidin dan Endri, 2010).

Hasil studi pendahuluan tentang kinerja perbankan syariah Cabang Bima ditemukan beberapa masalah seperti dalam tabel di bawah ini.

\begin{tabular}{|c|c|c|c|c|c|}
\hline \multicolumn{6}{|c|}{ TABEL 1 LAPORAN SNGKAT } \\
\hline \multicolumn{6}{|c|}{ KEUANGAN PT. BANK NTB SYARLAH KC BMA SOEKARNO HATTA TAHUN 2019} \\
\hline \multirow{2}{*}{ No } & \multirow{2}{*}{ URAIAN } & \multicolumn{2}{|c|}{ CABANG BIIA } & \multirow{2}{*}{$\begin{array}{c}\text { TARGET } \\
\text { IRIWULAN } \\
\text { III }\end{array}$} & \multirow{2}{*}{ PENCAPAIAI } \\
\hline & & 31 AGUSTUS 2019 & 30 September 2019 & & \\
\hline 1 & $\begin{array}{c}\text { DANA PIHAK } \\
\text { KETIGA } \\
\text { (DPK) }\end{array}$ & $461,801,842,808$ & $608,746,263,927$ & $696,497,000,000$ & $87.40 \%$ \\
\hline 2 & PENBIAYAAN & $371,339,677,132$ & $380,466,309,573$ & $448,960,000,000$ & $84.74 \%$ \\
\hline 3 & PENDAPATAN & $25,876,015,999$ & $29,252,063,508$ & $63,763,000,000$ & $45.88 \%$ \\
\hline 4 & NPF & $1.20 \%$ & $1.16 \%$ & $0.75 \%$ & $64.27 \%$ \\
\hline 5 & LABA/RUGI & $17,461,688,422$ & $19,759,512,599$ & $38,059,000,000$ & $51.92 \%$ \\
\hline
\end{tabular}

Tabel 1 di atas dapat dijelaskan bahwa secara umum (rata-rata) pencapaian kinerja Bank NTB Syariah Kantor Cabang Bima ditemukan beberapa masalah karena belum mencapai target seperti Dana Pihak Ketiga (DPK) baru tercapai $87.40 \%$ artinya masih $12.60 \%$, kemudian pembiayaan yang tercapai $84.74 \%$ artinya masih $15.26 \%$ yang menjadi masalah pencapaian target, demikian juga pendapatan hanya mencapai $45.88 \%$ artinya masih $54.12 \%$ yang menjadi pekerjaan rumah (PR) bagi Bank NTB Syariah Cabang Bima. Berikutnya Non Performing Finance juga baru mencapai $1.16 \%$ atau $64.27 \%$ dari target yang ditetapkan, sedangkan target harus mencapai $0.75 \%$, sementara untuk laba baru mencapai $51.92 \%$.

Untuk mencapai target dan tujuan organisasi Bank NTB syariah tersebut tidak mudah, oleh karena itu dibutuhkan kepemimpinan yang bisa menciptakan iklim kerja yang menyenangkan bagi pegawai sehingga menciptakan motivasi dan kepuasan Jurnal Ilmu Sosial dan Pendidikan kerja pegawai. Hasil penelitian Alfiah (2013) kepemimpinan memiliki andil besar terhadap kinerja bawahan dalam menjalankan tugasnya. Menurut Robbins (2010) kepemimpinan yang baik dan sesuai dengan iklim kerja dapat memotivasi dan memberikan perhatian, mampu melatih, serta membuat seseorang loyal terhadap organisasi. Pengaruh kepemimpinan membuat pegawai lebih memiliki rasa loyalitas terhadap pekerjaanya. Gaya kepemimpinan yang proposional terhadap keadaan dan lingkungan kerja dapat memberi kepuasan tersendiri bagi bawahan. Penelitian Zafer (2012) menemukan bahwa gaya kepemimpinan tidak memiliki pengaruh signifikan terhadap kinerja karyawan.

Kepuasaan kerja merupakan salah satu faktor penentu bagi pegawai dalam meningkatkan kinerja. Kepuasan kerja harus dapat dipahami oleh pimpinan dalam menerapkan kebijakan yang menyangkut pengelolaan sumber daya manusia. Oleh karena itu penting untuk memahami kepuasan kerja dari setiap pegawai dalam meningkatkan produktivitas kerja. Kepuasan kerja merupakan suatu hal yang bersifat individu karena setiap individu memiliki indikator kepuasan kerja yang berbeda dan beragam. Semakin banyak aspek yang sesuai dengan diri seorang maka semakin besar pula tingkat kepuasan kerja yang dirasakan. Penelitian Wanda Febriyana (2015) bahwa kepuasan kerja mempunyai pengaruh dominan terhadap kinerja pagawai. Dengan dimilikinya kepuasaan kerja maka akan memotivasi pegawai untuk bekerja dengan penuh tanggung jawab dan professional karena motivasi menjadi pendorong seseorang dalam melaksanakan kegiatan guna mendapat hasil yang terbaik. Berbeda dengan hasil penelitian Agung (2013) bahwa kepuasan kerja tidak berpengaruh signifikan terhadap kinerja.

Menurut Sunarto (2013:94) perlu adanya motivasi bagi pegawai untuk berbuat semaksimal mungkin dalam melaksanakan tugasnya, sebaliknya apabila pemberian motivasi kurang diperhatikan, maka tidak akan ada semangat dan gairah bekerja, akan berpengaruh pada kinerja. Pemberian 
motivasi dilakukan dengan memberi dorongan agar diciptakan keinginan kerja yang tinggi dan dapat menimbulkan semangat bekerja sehingga memiliki akan bekerja secara maksimal sesuai dengan yang diharapan. Kurangnya motivasi pegawai dalam mengikuti apel pagi atau terlambat dan kurangnya semangat dalam menjalankan tugas sesuai dengan target yang telah ditetapkan yang akan berpengaruh pada kinerja. Penelitian Supriyatno (2017) menemukan terdapat pengaruh positif yang signifikan motivasi terhadap kinerja karyawan, namun berbeda dengan hasil penelitian Abidin (2013) bahwa motivasi tidak berpengaruh signifikan terhadap kinerja pegawai.

Berdasarkan fenomena yang terjadi dan research gap yang ada sebelumnya tujuan penelitian ini adalah untuk:

1. Menganalisis pengaruh gaya kepemimpinan transformasional terhadap kinerja pegawai Bank NTB Syariah pada Kantor Cabang Bima.

2. Menganalisis pengaruh kepuasan kerja terhadap kinerja pegawai Bank NTB Syariah pada Kantor Cabang Bima.

3. Menganalisis pengaruh motivasi kerja terhadap kinerja pegawai Bank NTB Syariah pada Kantor Cabang Bima.

4. Menganalisis pengaruh simultan gaya kepemimpinan transformasional, kepuasan kerja dan motivasi kerja terhadap kinerja pegawai Bank NTB Syariah pada Kantor Cabang Bima.

\section{KAJIAN PUSTAKA \\ Bank Syariah}

Kegiatan ekonomi sudah ada jauh sebelum jaman Rasulullah SAW. Setelah meninggalnya Nabi Muhammad SAW Oleh banyak pro kontra ekonomi yang dihadapi manusia, maka ahli pikir mulai memikirkan bagaimana mengubah seni berekonomi menjadi ilmu ekonomi seperti yang ada sekarang ini. Dengan melihat perkembangan Bank Syariah di dunia maka gagasan dan konsep ekonomi Syariah akan terus ikut bersaing dengan ekonomi konvensional bahkan lebih berkembang pesat dari konsep ekonomi neoklasik (Marimin dan Romdhoni, 2015). Hal ini didasari pada satu gagasan dan keyakinan bahwa bank pada umumnya merupakan sistem keuangan berbasis Islam. Pada prespektif sejarah Bank Syariah dikembangkan sebagai suatu respon dari kelompok ekonomi dan praktisi perbankan muslim yang mencoba mengakomodasi desakan dari berbagai pihak yang menginginkan agar tersedia jasa transaksi keuangan yang dilaksanakan sejalan dengan nilai prinsip-prinsip Islam. Sehingga umat Islam diharapkan dapat memahami perkembangan bank Syariah dan mengembangkannya apabila dalam posisi sebagai pengelola secara cermat mengenali dan mengidentifikasi semua mitra kerja yang sudah ada maupun yang potensial untuk pengembangan bank syariah.

Di Indonesia sendiri pelopor perbankan syariah adalah Bank Muamalat Indonesia. Berdiri tahun 1991, bank ini diprakarsai oleh Majelis Ulama Indonesia (MUI) dan pemerintah serta dukungan dari Ikatan Cendekiawan Muslim Indonesia (ICMI) dan beberapa pengusaha muslim. Bank ini sempat terimbas oleh krisis moneter pada akhir tahun 90-an sehingga ekuitasnya hanya tersisa sepertiga dari modal awal. IDB kemudian memberikan suntikan dana kepada bank ini dan pada periode 1999-2002 dapat bangkit dan menghasilkan laba. Kebutuhan untuk melakukan perubahan sistem keuangan perbankan menjadi penting, mengingat sistem perbankan dalam kehidupan ekonomi modern memegang peranan yang cukup dominan, khususnya bagi Negara-negara yang berpenduduk muslim. Perubahan sistem dilakukan dengan konseptualisasi sistem perbankan yang bersumber dari interpretasi terhadap konsep dasar Islam. Sebagai Financial Intermediary Institution perbankan syariah menawarkan beberapa produk, baik produk yang berupa penghimpunan dana (funding) yang meliputi; wadi'ah dan mudharabah, penyaluran dana (financing), seperti; jual-beli (murabahah, salam, dan istishna'), ijarah, bagi hasil (musyarakah dan mudharabah) maupun jasa-jasa lainnya (services) berdasarkan prinsip syariah, seperti 
hiwalah, rahn, kafalah, dan sarf (Fahmi, 2012).

Perbankan syariah beroperasi dengan berlandaskan Undang-undang No. 21 Tahun 2008 tentang Perbankan Syariah. Produk perbankan syariah sebagaimana yang tertuang dalam UU dan SK Direksi BI tersebut di atas merupakan penjabaran dari konsep dasar syari'at Islam yang dilakukan oleh Dewan Syariah Nasional MUI melalui fatwanya, baik yang merujuk langsung kepada Al-Qur'an dan Hadis maupun pada literatur hukum Islam (fiqh). Pertumbuhan keuangan Islam pada awalnya juga bertepatan dengan surplus neraca pembayaran yang sangat besar pada negara-negara muslim pengekspor minyak, yang dikenal sebagai "oil booming" pada dekade 70-an (Angelo 2011). Selain itu, hal ini juga dipengaruhi oleh faktor-faktor yang lain, seperti keinginan perubahan terhadap sistem sosio-politik dan ekonomi yang berlandaskan prinsip-prinsip Islam dan kepribadian Islam yang lebih kuat, sekaligus sebagai upaya reformasi makro ekonomi dan reformasi struktural dalam sistem keuangan negara-negara muslim (Anshori, 2012).

\section{Kepemimpinan Transformasional}

Kepemimpinan transformasional berusaha untuk menginspirasi kinerja yang luar biasa. Gaya kepemimpinan transformasional memiliki berbagain cara untuk memberikan motivasi kepada pengikutnya agar dapat meningkatkan kinerja pengikutnya dengan cara memberikan dorongan yang lebih kepada pengikut, memberikan contoh untuk lebih mementingkan kelompok dari pada individu untuk kebaikan bersama, dan memberikan fasilitas kepada pengikut untuk lebih semangat dalam bekerja. Mangkunegara (2011) menyatakan bahwa kepemimpinan transformasional adalah suatu model kepemimpinan untuk meningkatkan sumberdaya manusia dengan dan hubungan efek 25 pemimpin terhadap bawahan dapat diukur, dengan indikator adanya kepercayaan, kekaguman, kesetiaan, dan hormat terhadap pemimpin, berusaha untuk memotivasi pengikut untuk melakukan sesuatu yang lebih demi tercapainya kinerja.

Keller(1992) dikutip Mangkunegara (2011) mengemukakan bahwa Kepemimpinan Transformational adalah sebuah gaya kepemimpinan yang mengutamakan pemenuhan terhadap tingkatan tertinggi dari hirarki maslow yakni kebutuhan akan harga diri dan aktualisasi diri. Locke (1997) menjelaskan kepemimpinan transformasional diartikan sebagai kepemimpinan yang sejati karena kepemimpinan ini sungguh bekerja menuju sasaran pada tindakan mengarahkan organisasi kepada suatu tujuan yang tidak pernah diraih sebelumnya. Kepemimpinan ini juga didefinisikan sebagai kepemimpinan yang membutuhkan tindakan memotivasi para bawahan agar bersedia bekerja demi sasaransasaran tingkat tinggi yang dianggap melampaui kepentingan pribadinya pada saat itu (Burns, 1978 dikutip Hasibuan 2010).

Menurut Bass (2006) dan Cheok (2012) beberapa indikator kepemimpinan Transformasional sebagai berikut:

$\checkmark$ Idealized Influence (karisma). Pemimpin menampilkan keyakinan, menekankan kepercayaan, mengambil isu-isu yang sulit, menyajikan nilai-nilai mereka yang paling penting, dan menekankan pentingnya tujuan, komitmen, dan konsekuensi etis dari keputusan. Pemimpin seperti dikagumi sebagai pembangkit panutan kebanggaan, loyalitas, kepercayaan, dan keselarasan sekitar tujuan bersama.

$\checkmark$ Motivasi Inspirasional. Pemimpin mengartikulasikan visi menarik dari masa depan, menantang pengikut dengan standar yang tinggi, berbicara optimis dengan antusias, dan memberikan dorongan dan makna untuk apa yang perlu dilakukan.

$\checkmark$ Stimulasi Intelektual. Pemimpin mempertanyakan cara lama, tradisi, dan keyakinan, merangsang perspektif baru dan cara melakukan sesuatu, dan mendorong ekspresi ide dari bawahan.

$\checkmark$ Pertimbangan Individual. Pemimpin berhubungan dengan orang lain (bawahan) secara personal, 
mempertimbangkan kebutuhan mereka, kemampuan, dan aspirasi, mendengarkan dengan penuh perhatian, pengembangan lebih lanjut mereka, menasihati, mengajar dan melatih.

\section{Kepuasan Kerja}

Kepuasan kerja adalah keadaan seseorang telah mencapai kepuasan psikologis yang memunculkan sikap positif yang mendorong semangat kerja (Rivai dan Sagala, 2010). Menurut Sinambela (2012: 258) kepuasan kerja adalah perasaan seseorang terhadap pekerjaannya yang dihasilkan oleh usahanya sendiri (internal) dan yang didukung oleh hal-hal yang dari luar dirinya (eksternal), atas keadaan kerja, hasil kerja, dan kerja itu sendiri. Mangkunegara (2010) menjelaskan konsep kepuasan kerja, meliputi: Pertama, teori keseimbangan (equity theory), teori ini dikembangkan oleh Adams. Komponen utama dari teori ini adalah. Input merupakan suatu nilai yang diberikan pekerja saat melaksanakan pekerjaannya. Outcome adalah semua nilai yang diperoleh seseorang dari pekerjaannya. Comparison person adalah seorang yang berada dalam organisasi yang sama ataupun diluar organisasi, atau dirinya sendiri dalam pekerjaan sebelumnya, equityinequity adalah suatu yang dirasakan karyawan adil atau tidak adil.

Kedua, teori perbedaan (discrepancy theory), teori ini pertama kali dikemukan oleh Porter yang berpendapat bahwa mengukur kepuasan kerja dapat dilakukan dengan cara menghitung selisih antara apa yang seharusnya dengan kenyataan yang dirasakan pegawai. Kepuasan kerja pegawai bergantung pada perbedaan antara apa yang didapat dan apa yang diharapkan oleh pegawai. Ketiga, Teori pemenuhan kebutuhan (need fulfillment theory), menurut teori ini kepuasan kerja pegawai bergantung pada terpenuhinya atau tidak nya kebutuhan pegawai. Keempat, pandangan kelompok (social reference group theory), pada teori ini, kepuasan kerja karyawan bukanlah bergantung pada pemenuhan kebutuhan saja, tetapi juga bergantung pada pandangan dan pendapat kelompok yang dianggap sebagai kelompok acuan.

Kelima, teori dua faktor dari Herzberg. Berdasarkan teori ini kepuasan kerja dan ketidakpuasan kerja itu terpisah dan berbeda. Teori ini merumuskan dua faktor yaitu satisfies atau motivators dan dissatisfies atau hygiene factors. Keenam, teori pengharapan (expectancy theory) Vroom menjelaskan bahwa motivasi merupakan suatu produk dari bagaimana seorang menginginkan sesuatu, dan penaksiran seseorang memungkinkan aksi tertentu yang menuntunnya. Kepuasan kerja yang dirasakan karyawan dari pekerjaannya diperoleh dari beberapa dimensi (Ivancevich et al. 2010:90), yaitu: imbalan, pekerjaan itu sendiri, peluang promosi, supervisi, rekan kerja, kondisi pekerjaan dan keamanan pekerjaan.

Mangkunegara (2010:93) menyatakan bahwa ada sejumlah faktor yang mempengaruhi kepuasan kerja. Hal-hal utama dengan mengingat dimensi-dimensi paling penting yaitu gaji, pekerjaan itu sendiri, promosi, pengawasan, kelompok kerja dan kondisi kerja. Kepuasan kerja dipengaruhi 5 dimensi spesifik dari pekerjaan yaitu gaji, pekerjaan itu sendiri, kesempatan promosi, supervisi dan rekan kerja.Menurut Hasibuan (2011)kepuasan kerja karyawan dipengaruhi oleh faktor-faktor:

$\checkmark$ Balas jasa yang adil dan layak.

$\checkmark$ Penempatan yang tepat sesuai dengan keahlian.

$\checkmark$ Berat ringannya pekerjaan.

$\checkmark$ Suasana dan lingkungan pekerjaan.

$\checkmark$ Peralatan yang menunjang pelaksanaan pekerjaan.

$\checkmark$ Sikap pimpinan dalam kepemimpinannya.

$\checkmark$ Sifat pekerjaan monoton atau tidak.

\section{Motivasi Kerja}

Motivasi adalah keinginan dalam diri seseorang yang merangsang ia melakukan tindakan. Derajat atau keadaan rangsangan tersebut tergantung pada pengharapan pribadi terhadap suatu tingkat kepuasan perasaan yang bisa dicapai. Motivasi merupakan dorongan yang ada di dalam diri manusia yang menyebabkannya melakukan sesuatu 
atau berbuat sesuatu. Motivasi merupakan keinginan, hasrat dan tenaga penggerak yang berasal dari dalam diri manusia, oleh karena berhubungan dengan faktor psikologis seseorang yang mencerminkan hubungan atau interaksi antara sikap, kebutuhan dan kepuasan yang terjadi pada diri manusia. Motivasi merupakan faktor internal yang mempengaruhi sikap dan perilaku seseorang dalam bekerja karena dorongan kebutuhan atau keinginan tertentu.

Lubis (2016) mengungkapkan mengenai teori motivasi Abraham Maslow bahwa individu akan termotivasi untuk memenuhi kebutuhan yang dimulai dengan kebutuhan fisik (sandang dan pangan) kemudian berusaha memenuhi kebutuhan yang lebih tinggi lagi. Menurut Clayton Alderfer bahwa setiap orang mempunyai kebutuhan tersusun dalam suatu hirarki-mulai dari kebutuhan eksistensi (existence), kebutuhan relasi (relatedness) hingga kebutuhan pertumbuhan (growth).

Lubis (2016:93) menjelaskan teori motivasi Mc.Clelland bawha terdapat tiga jenis kebutuhan manusia, antara lain; kebutuhan berprestasi (need for achievement), kebutuhan berkuasa (need for power), dan kebutuhan berafiliasi (need for affiliation). Pendapat Adam bahwa seseorang membandingkan usaha mereka dengan orang lainnya dalam situasi kerja yang sama. Selain itu bahwa orang yang dimotivasi untuk diperlakukan secara adil. Bila pegawai diperlakukan secara tidak adil, maka motivasinya akan menurun. Sebaliknya jika merasa diperlakukan adil, maka motivasinya akan bertambah. Menurut McClelland dalam Robbins (2011:174) indikator-indikator motivasi kerja adalah:

$\checkmark$ Kebutuhan akan kekuasaan

$\checkmark$ Kebutuhan untuk berprestasi

$\checkmark$ Kebutuhan akan afiliasi

\section{Kinerja Pegawai}

Menurut Mahsun, et al, (2013:141), kinerja merupakan gambaran umum tingkat pelaksanaan suatu kegiatan dalam mewujudkan tujuan organisasi yang tertuang dalam strategic planning suatu organisasi. Mangkunegara (2010:67) yang

Jurnal Ilmu Sosial dan Pendidikan mendefinisikan kinerja sebagai hasil keja secara kualitas dan kuantitas yang dicapai oleh seorang pegawai dalam melaksanakan tugasnya sesuai dengan tanggung jawab yang diberikan kepadanya. Hasibuan (2011:94) menilai adalah suatu hasil kerja yang dicapai seseorang dalam melakukan tugas-tugas yang dibebankan kepadanya didasarkan atas kecakapan, pengalaman, dan kesungguhan serta waktu. Prestasi kerja pada umumnya dikaitkan dengan pencapaian hasil standar kerja yang telah ditetapkan. Hasibuan (2011) menjelaskan kriteria yang perlu mendapat perhatian dalam mengukur kinerja, antara lain:

$\checkmark$ Kuantitas kerja (quantity of work), yaitu jumlah kerja yang dilakukan dalam suatu periode waktu yang ditentukan.

$\checkmark$ Kualitas kerja (quality of work), yaitu kualitas yang dicapai berdasarkan syaratsyarat kesesuaian dan kesiapannya.

$\checkmark$ Pengetahuan kerja (job knowledge) yaitu luasnya pengetahuan mengenai pekerjaan dan keterampilannya.

$\checkmark$ Kreativitas (creativity), yaitu keaslian gagasan yang dimunculkan dan tindakan tindakan untuk menganalisis persoalan persoalan yang timbul.

$\checkmark$ Kerja sama (cooperation), yaitu kesediaan untuk bekerja sama dengan orang lain (sesama anggota organisasi).

$\checkmark$ Tanggung jawab (dependability), yaitu kesadaran dan dapat dipercaya dalam hal kehadiran.

$\checkmark$ Inisiatif (initiative), yaitu semangat untuk melaksanakan tugas-tugas baru dalam memperbesar tanggug jawab.

\section{Penelitian Terdahulu}

Berikut ringkasan kajian hasil penelitian sebelumnya seperti dalam tabel di bawah ini.

Tabel 2 Penelitian Terdahulu yang Relevan dengan Penelitian ini

\begin{tabular}{|l|l|l|l|l|}
\hline No & Penulis & Judul & Metode & Kesimpulan \\
\hline 1 & Pariari & Pengaruh Gaya & Independen: & Gaya \\
& bo & Kepemimpinan, & Gaya & Kepemimpinan, \\
& $(2014)$ & dan Motivasi & kepemimpinan, & Motivasi Kerja, \\
& & Kerja Terhadap & Motivasi keirja, & Kepuasan Kerja \\
& & Kepuasan Kerja & Kepuasan kerja. & berpengaruh \\
& & Serta Dampaknya & Dependen: & signifikan \\
& & Terhadap Kinerja & Kinerja & Kinerja \\
& & Pegawai Badan & Analisis: & Pegawai \\
& & Perencanaan & Jalur/Path & \\
& & Pembangunan & & \\
& & & & \\
\end{tabular}




\begin{tabular}{|c|c|c|c|c|}
\hline & & $\begin{array}{l}\text { Daerah di } \\
\text { Kabupaten } \\
\text { Supiori }\end{array}$ & & \\
\hline 2 & $\begin{array}{l}\text { Basit } \\
\text { dan } \\
\text { Sebasti } \\
\text { an } \\
(2017)\end{array}$ & $\begin{array}{l}\text { Impact Of } \\
\text { Leadership Style } \\
\text { On Employee } \\
\text { Performance (A } \\
\text { Case Study On A } \\
\text { Private } \\
\text { Organization In } \\
\text { Malaysia). } \\
\end{array}$ & $\begin{array}{l}\text { Independen: } \\
\text { Leadership Style } \\
\text { Dependen: } \\
\text { Employee } \\
\text { Performance }\end{array}$ & $\begin{array}{l}\text { Gaya } \\
\text { kepemimpinan } \\
\text { memiliki } \\
\text { pengaruh } \\
\text { positif dan } \\
\text { signifikan } \\
\text { terhadap kinerja } \\
\text { karyawan. } \\
\end{array}$ \\
\hline 3 & $\begin{array}{l}\text { Avilla } \\
(2017)\end{array}$ & $\begin{array}{l}\text { Gaya } \\
\text { Kepemimpinan } \\
\text { Organisasi, dan } \\
\text { Reaksi Karyawan } \\
\text { Terhadap Kinerja } \\
\text { Karyawan }\end{array}$ & $\begin{array}{l}\text { Independen: } \\
\text { Gaya } \\
\text { Kepemimpinan } \\
\text { Dependen: } \\
\text { Kinerja } \\
\text { Karyawan }\end{array}$ & $\begin{array}{l}\text { Gaya } \\
\text { Kepemimpinan } \\
\text { Berpengaruh } \\
\text { SignifikanTerh } \\
\text { adap Kinerja } \\
\text { Karyawan } \\
\end{array}$ \\
\hline 4 & $\begin{array}{l}\text { Parach } \\
\text { a, et al } \\
\text { (2012) }\end{array}$ & $\begin{array}{l}\text { Impact of } \\
\text { Leadership Style } \\
\text { (Transformational } \\
\text { \& Transactional } \\
\text { Leadership) On } \\
\text { Employee } \\
\text { Performance \& } \\
\text { Mediating Role of } \\
\text { Job Satisfaction } \\
\text { Study of Private } \\
\text { School (Educator) } \\
\text { In Pakistan. }\end{array}$ & $\begin{array}{l}\text { Independen: } \\
\text { Gaya } \\
\text { Kepemimpinan } \\
\text { Moderator: } \\
\text { Kepusan Kerja } \\
\text { Dependen: } \\
\text { Kinerja } \\
\text { Karyawan }\end{array}$ & $\begin{array}{l}\text { Gaya } \\
\text { kepemimpinan } \\
\text { baik } \\
\text { transaksional } \\
\text { maupun } \\
\text { transformasiona } \\
1 \text { berpengaruh } \\
\text { positif terhadap } \\
\text { kinerja } \\
\text { karyawan. } \\
\text { Kepemimpinan } \\
\text { transaksional } \\
\text { lebih } \\
\text { berpengaruh } \\
\text { signifikan } \\
\text { dibandingkan } \\
\text { kepemimpinan } \\
\text { transformasiona } \\
\text { l. }\end{array}$ \\
\hline 5 & $\begin{array}{l}\text { Kashif } \\
\text { Rathor } \\
\text { e dan } \\
\text { Chaud } \\
\text { hry } \\
\text { Abdul } \\
\text { Khaliq } \\
(2017)\end{array}$ & $\begin{array}{l}\text { The Influence of } \\
\text { Leadership Styles } \\
\text { on Employees } \\
\text { Performance } \\
\text { under Perceptions } \\
\text { of Organizational } \\
\text { Politics: A Study } \\
\text { of Telecom Sector } \\
\text { in Pakistan. }\end{array}$ & $\begin{array}{l}\text { Independen: } \\
\text { Gaya } \\
\text { Kepemimpinan } \\
\text { Dependen: } \\
\text { Kinerja } \\
\text { Karyawan }\end{array}$ & $\begin{array}{l}\text { Menunjukkan } \\
\text { bahwa } \\
\text { transformasiona } \\
1 \\
\text { kepemimpinan } \\
\text { tidak } \\
\text { berhubungan } \\
\text { erat dengan } \\
\text { kinerja } \\
\text { karyawan } \\
\text { sedangkan } \\
\text { kepemimpinan } \\
\text { transaksional } \\
\text { terkait secara } \\
\text { signifikan } \\
\text { dengan kinerja } \\
\text { karyawan. }\end{array}$ \\
\hline
\end{tabular}

Sumber: Diolah Peneliti, 2019

Penelitian ini tidak bersifat mengulang namun hanya memodifikasi penelitian sebelumnya dengan beberapa tambahan variabel independen lainnya. Dengan kata lain penelitian yang dilakukan ini memperkuat penelitian-penelitian sebelumnya yang terkait dengan kinerja pegawai pada suatu organisasi khusunya pada Bank Syariah Kantor Cabang Bima.

\section{Hipotesis Penelitian}

Dari kajian teori dan penelitian terdahulu seperti yang telah dijelaskan pada hubungan variabel penelitian di atas, maka adapun hipotesis penelitian yang diajukan dalam penelitian ini adalah:
1. Gaya Kepemimpinan Transformasional Berpengaruh Signifikan dan Positif Terhadap Kinerja Pegawai pada Bank NTB Syariah Kantor Cabang Bima.

2. Kepuasan Kerja Berpengaruh Signifikan dan Positif Terhadap Kinerja Pegawai pada Bank NTB Syariah Kantor Cabang Bima.

3. Motivasi Kerja Berpengaruh Signifikan dan Positif Terhadap Kinerja Pegawai pada Bank NTB Syariah Kantor Cabang Bima.

4. Gaya Kepemimpinan Transformasional, Kepuasan Kerja dan Motivasi Kerja Berpengaruh Signifikan dan Positif Terhadap Kinerja Pegawai pada Bank NTB Syariah Kantor Cabang Bima.

\section{METODE PENELITIAN}

Desain yang digunakan termasuk korelasional yaitu peneliti yang fokus untuk mengungkap hubungan sebab-akibat antara variabel independen dengan variabel dependen. Penelitian dilaksanakan pada Bank NTB Syariah Kantor Cabang Bima berlokasi di Jalan Soekarno Hatta No. 8 Kelurahan Dara Kecamatan Rasanae Barat Kota Bima dengan waktu penelitian mulai tanggal 6 November 2020 sampai dengan tanggal 31 Desember 2020. Populasi penelitian adalah seluruh pegawai Bank NTB Syariah Kantor Cabang Bima yang berjumlah 54 orang pegawai. Mengingat populasi penelitian sebanyak 54 orang pegawai pegawai Bank NTB Syariah Kantor Cabang Bima maka teknik pengambalan sampel dalam penelitian ini adalah dengan menggunakan teknik sensus dengan pendekatan non probabilitas. Instrumen penelitian ini berupa kuesioner dengan menggunakan skala likert. Data dianalisis dengan menggunakan Metode Analisis Regresi Liner Berganda dengan persamaan regresi berganda sebagai berikut:

$$
\breve{Y}=\alpha+\beta X_{1}+\beta X_{2}+\beta X_{3}
$$

Keterangan:

$$
\begin{array}{ll}
\breve{Y} & =\text { Kinerja Pegawai } \\
\alpha & =\text { Konstan } \\
\beta & =\text { Koefisien Estimasi } \\
X_{1} & =\text { Kepemimpinan Transformasional }
\end{array}
$$


$X_{2} \quad=$ Kepuasan Kerja

$X_{3}=$ Motivasi Kerja

\section{HASIL PENELITIAN \\ Karakteristik Responden Penelitian}

Setelah melakukan kegiatan penelitian peneliti dapat mengetahui klarifikasi data responden ditinjau dari jenis kelamin yang berjenis kelamin perempuan mendominasi dibandingkan dengan responden yang berjenis kelamin laki-laki dimana $35 \%$ jumlah responden laki-laki dan $65 \%$ responden perempuan. Responden memiliki jenjang pendidikan terakhir yang heterogen (beragam), semuanya berpendidikan terakhir jenjang Strata Satu (S1). Hal ini menunjukkan bahwa tingkat pendidikan pegawai Bank NTB Syariah Cabang Bima cukup mampu dalam menjalankan tugas-tugas yang diberikan sesuai bagiannya masing-masing dan kemampuanya. Data tentang umur/usia respoden penelitian bahwa usia $\leq 30$ sebanyak 30 orang atau $79 \%$ dan usia responden berada pada $\geq 40$ tahun sebanyak 11 orang atau $21 \%$. Masa kerjaresponden penelitian memiliki masa kerja $\leq 5$ tahun sebanyak 8 orang atau $15 \%$. Pegawai memiliki masa kerja lebih dari 6-10 tahun sebanyak 28 orang atau $52 \%$ Responden memiliki masa kerja $\geq 11$ tahun sebanyak 18 orang atau $33 \%$.

\section{Analisis Deskriptif}

Hasil analisis deskriptif dalam tabel tersebut di atas menunjukkan bahwa rata-rata responden memberi penilaian mengenai kepemimpinan pada kategori sangat baik, yaitu 33 orang atau $61 \%$, dan ada 21 orang atau $39 \%$ berada pada kategori tinggi. hasil analisis deskriptif menunjukkan bahwa ratarata kepuasan pegawai berada pada kategori tinggi, yaitu 28 orang atau 52\%, ada 24 orang atau $44 \%$ berada pada kategori sangat tinggi, dan ada 2 orang atau $4 \%$ berada pada kategori cukup. Hasil analisis deskriptif menunjukkan bahwa rata-rata motivasi kerja berada pada kategori tinggi, yaitu 26 orang atau 49\%, ada 24 orang atau $44 \%$ berada pada kategori sangat tinggi, dan ada 4 orang atau $7 \%$ berada pada kategori cukup. Hasil analisis deskriptif menunjukkan bahwa rata-rata kinerja pegawai berada pada kategori sangat tinggi, yaitu 30 Jurnal Ilmu Sosial dan Pendidikan orang atau 56\%, ada 24 orang atau $44 \%$ berada pada kategori tinggi.

\section{Uji Asumsi Klasik Normalitas}

Sebelum melakukan analisis regresi berganda dilakukan uji normalitas yang betujuan untuk mengetahui apakah data berdistribusi normal atau tidak. Pengambilan keputusan dilakukan jika asymp sig. lebih besar (>) 0,05 maka data berdistribusi normal. Berdasarkan kaidah itu maka semua variabel penelitian memiliki data berdistribusi normal. Adapaun hasil analisis uji normalitas masingmasing variabel penelitian dapat dilihat pada tabel berikut

Tabel 3 Hasil Uji Normalitas Data

\begin{tabular}{|c|c|c|c|c|c|}
\hline \multicolumn{6}{|c|}{ One-Sample Kolmogorov-Smirnov Test } \\
\hline & & Kepemimpinan & Kepuasan Kerja & Motivasi & Kinerja \\
\hline \multicolumn{2}{|l|}{$\mathrm{N}$} & 54 & 54 & 54 & 54 \\
\hline \multirow{2}{*}{ Normal Parameters ${ }^{\mathrm{a}}$} & Mean & 40.28 & 37.96 & 39.52 & 44.37 \\
\hline & Std. Deviation & 5.482 & 5.563 & 5.237 & 5.485 \\
\hline \multirow{3}{*}{$\begin{array}{l}\text { Most Extreme } \\
\text { Differences }\end{array}$} & Absolute & .131 & .096 & .093 & .111 \\
\hline & Positive & .131 & .073 & .058 & .087 \\
\hline & Negative & -.111 & -.096 & -.093 & -.111 \\
\hline \multicolumn{2}{|c|}{ Kolmogorov-Smimov Z } & .965 & .708 & .684 & .813 \\
\hline \multicolumn{2}{|c|}{ Asymp. Sig. (2-tailed) } & 0.309 & 0.698 & 0.737 & 0.524 \\
\hline \multicolumn{2}{|c|}{ a. Test distribution is Normal. } & & & & \\
\hline
\end{tabular}

\section{Linieritas}

Uji linieritas dilakukan untuk mengetahui apakah semuan variabel penelitian memiliki pola hubungan yang linier dengan ketentuan apa bila signifikan lebih besar (>) 0,05 maka dinyatakan linier. Barikut hasil analisis uji linieritas.

Tabel 5 Hasil Uji Linieritas

\begin{tabular}{|l|l|l|}
\hline \multicolumn{3}{|c|}{ ANova Table } \\
\hline Kinerja Pegawai * Kepemimpinan & Deviation from Linearity &. $\mathbf{1 8 9}$ \\
\hline Kinerja Pegawai * Kepuasan Kerja & Deviation from Linearity &. $\mathbf{3 6 8}$ \\
\hline Kinerja Pegawai * Motivasi Kerja & Deviation from Linearity & $\mathbf{. 1 2 4}$ \\
\hline
\end{tabular}

\section{Multikolinieritas}

Adapun hasil uji multikolinieritas dalam penelitian menggunakan bantuan SPSS 16 diketahui bahwa semuan varibel penelitian tidak terjadi multikolineritas karena nilai Tolerance lebih kecil (<) 10 dan nilai VIF lebih besar (>)10 dan tabel hasil analisis ditampilkan dapat dilihat pada tabel berikut. 


\begin{tabular}{|c|c|c|c|c|c|c|}
\hline \multicolumn{2}{|c|}{ Simbol } & \multicolumn{5}{|c|}{ Penjelasan } \\
\hline \multicolumn{2}{|c|}{$b o$} & \multicolumn{5}{|c|}{$\begin{array}{l}\text { Mengisyaratkan bahwa jika dalam } \\
\text { melaksanakan tugas dan tanggung } \\
\text { jawab sebagai pegawai pada Bank } \\
\text { NTB Syariah Cabang Bima jika } \\
\text { tidak memiliki kepemimpinan yang } \\
\text { mendukung terhadap pelaksanaan } \\
\text { tugas, kepuasan kerja dan motivasi } \\
\text { kerja dari pegawai maka kinerja } \\
\text { kinerja pegawai sebesar } 0.427\end{array}$} \\
\hline \multicolumn{2}{|c|}{$b_{1} \mathrm{X}_{1}$} & \multicolumn{5}{|c|}{$\begin{array}{l}\text { Mengisyaratkan bahwa jika } \\
\text { kepimimpinan transformasional naik } \\
1 \text { satuan maka kinerja pegawai Bank } \\
\text { NTB Syariah Cabang Bima akan } \\
\text { naik sebesar 0.466. Artinya } \\
\text { pengaruh kepemimpinan terhadap } \\
\text { kinerja pegawai sebesar } \\
\left(0,466^{2}=21,7,8 \%\right) \text { dibulatkan } \\
\text { menjadi } 22 \text { dan sisanya dipengaruhi } \\
\text { oleh variabel lain. }\end{array}$} \\
\hline \multicolumn{2}{|c|}{$b_{2} \mathrm{X}_{2}$} & \multicolumn{5}{|c|}{$\begin{array}{l}\text { Mengisyaratkan bahwa jika } \\
\text { kepuasan kerja naik } 1 \text { satuan maka } \\
\text { kinerja pegawai Bank NTB Syariah } \\
\text { Cabang Bima akan naik sebesar } \\
0,509 \text {. Artinya pengaruh kepuasan } \\
\text { kerja terhadap kinerja pegawai } \\
\text { sebesar }\left(0,509^{2}=25,9\right) \text { dibulatkan } \\
\text { menjadi } 26 \% \text { dan sisanya } \\
\text { dipengaruhi oleh variabel lain. }\end{array}$} \\
\hline \multicolumn{2}{|c|}{$b_{3} \mathrm{X}_{3}$} & \multicolumn{5}{|c|}{$\begin{array}{l}\text { Mengisyaratkan bahwa jika motivasi } \\
\text { naik } 1 \text { satuan maka kinerja pegawai } \\
\text { Bank NTB Syariah Cabang Bima } \\
\text { akan naik sebesar } 0,563 \text {. Artinya } \\
\text { pengaruh terhadap motivasi kerja } \\
\text { terhadap kinerja pegawai sebesar } \\
(0,563)^{2}=31,7 \% \text { dibulatkan menjadi } \\
32 \% \text { dan sisanya dipengaruhi oleh } \\
\text { variabel lain. }\end{array}$} \\
\hline \multirow{2}{*}{\multicolumn{7}{|c|}{ Tabel 6 Hasil Uji Multikolinieritas }} \\
\hline & & & & & & \\
\hline \multirow{2}{*}{\multicolumn{2}{|c|}{ Model }} & \multicolumn{5}{|c|}{ Collinearity Statistics } \\
\hline & & & Std. Error & Beta & Tolerance & \\
\hline \multirow{4}{*}{1} & (Constant) & 19.427 & 5.180 & & & \\
\hline & Kepemimpin & .119 & .176 & .118 & .434 & 2.303 \\
\hline & Kepuasan Ker & .154 & .203 & .156 & .315 & 3.176 \\
\hline & Motivasi Ker & .363 & .268 & .346 & .205 & 4.871 \\
\hline & & & & & & \\
\hline
\end{tabular}

\section{Analisis Regresi Linier Berganda Pengaruh Parsial}

Adapun hasil analisis regresi berganda mengenai pengaruh parsial (sendiri-sendiri) masing-masing variabel kepemimpinan, kepuasan kerja dan motivasi terhadap variabel kinerja yaitu sebagai berikut: Jurnal Ilmu Sosial dan Pendidikan
Tabel 7 Hasil Analisis Pengaruh Parsial

\begin{tabular}{|c|c|c|c|c|c|c|}
\hline \multicolumn{7}{|c|}{ Coefficients $^{\mathrm{a}}$} \\
\hline & \multirow{2}{*}{ Model } & \multicolumn{2}{|c|}{ Unstandardized Coefficients } & \multirow{2}{*}{$\begin{array}{c}\text { Standardized } \\
\text { Coefficients }\end{array}$} & \multirow{2}{*}{$\mathrm{t}$} & \multirow[t]{2}{*}{ Sig. } \\
\hline & & $B$ & Std. Error & & & \\
\hline \multirow{4}{*}{1} & (Constant) & 0.427 & 5.180 & & 3.751 & .000 \\
\hline & Kepemimpinan & .466 & .123 & .466 & 3.796 & .000 \\
\hline & Kepuasan Kerja & .502 & .118 & .509 & 4.262 & .000 \\
\hline & Motivasi Kerja & .590 & .120 & .563 & 4.917 & .000 \\
\hline \multicolumn{4}{|c|}{ a. Dependent Variable: Kinerja Pegawai } & & & \\
\hline
\end{tabular}

Persamaan Regresi:

$$
\breve{Y}=0.427 \alpha+0.466 b X 1+0.509 b X 2+0.563
$$
$b \times 3$

Penjelasan Persamaan Regresi

Dari persamaan regresi linier berganda terlihat bahwa motivasi kerja memberikan pengaruh terbesar terhadap kinerja pegawai yang diikuti oleh kepuasa kerja dan gaya kepemimpinan. Dalam hal ini dapat diartikan pentingnya adanya insentif (kompensasi finansial) dan pengembangan karir (kompensasi non finansial) bagi pegawai Bank NTB Syariah Cabang Bima. Untuk itu dibutuhkan gaya kepemimpinan yang bersifat transformasional (visioner dan kolegial).

\section{Pengaruh Simultan}

Setelah mentahui pengaruh parsial dari masing-masing variabel penelitian maka selanjutnya dilakukan analisis untuk mengetahui pengaruh simultan (bersamasama) kepemimpinan, kepuasan kerja dan motivasi terhadap variabel kinerja pegawai sebagai berikut.

Tabel 8 Hasil Analisis Pengaruh Simultan

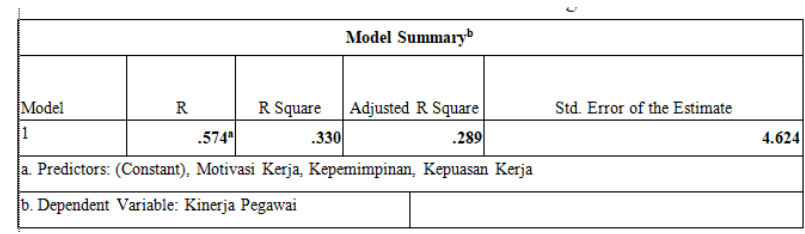

Tabel di atas menjelaskan bahwa $\mathrm{R}$ sebesar 0,547 adalah korelasi atau hubungan secara bersama-sama variabel indendependen dengan variabel dependen. Sedangkan besarnya pengaruh simultan gaya kepemimpinan transformasional, motivasi dan kepuasan terhadap kinerja pegawai Bank NTB Syariah Cabang Bima adalah $\left(0,547^{2}\right) \times 100=33 \%$ dan sisanya dipengaruhi oleh model lain. 


\section{Pengujian Hipotesis}

Pengaruh Parsial
Transformasional Tepemimpinan
Pegawai

Setelah dilakukan perhitungan diketahui bahwa t-hitung $=3.796>t$-tabel 2.307 dengan taraf signifikan $0,00<0,05$ artinya hipotesis nihil (H0) ditolak dan hipotesis alternatif (Ha) diterima dengan kata lain "Kepemimpinan Transformasional Memiliki Berpengaruh Signifikan dan Positif Terhadap Kinerja Pegawai Bank NTB Syariah Kantor Cabang Bima".

\section{Pengaruh Parsial Kepuasan Kerja Terhadap Kinerja Pegawai}

Setelah dilakukan perhitungan diketahui bahwa t-hitung $=4.262>\mathrm{t}$-tabel $=2.307$ dengan taraf signifikan $0,00<0,05$ artinya hipotesis nihil (H0) ditolak dan hipotesis alternatif $(\mathrm{Ha})$ diterima, artinya "Kepuasan Kerja Berpengaruh Signifikan dan Positif Terhadap Kinerja Pegawai Bank NTB Syariah Kantor Cabang Bima".

\section{Pengaruh Parsial Motivasi Kerja Terhadap Kinerja Pegawai}

Setelah dilakukan perhitungan diketahui bahwa t-hitung $=4.917>$ t-tabel 2.307 taraf signifikan $0,00<0,05$ artinya hipotesis alternatif (Ha) "Motivasi Kerja Berpengaruh Signifikan dan Positif Terhadap Kinerja Bank NTB Syariah Kantor Cabang Bima" diterima.

\section{Pengaruh Simultan Kepemimpinan} Transformasional, Kepuasan Kerja dan Motivasi Kerja Terhadap Kinerja Pegawai

Setelah dilakukan perhitungan diketahui bahwa taraf signifikan $0,00<0,05$ dan F-tabel $=8.193>$ F-tabel $=6.32$ artinya hipotesis nihil (H0) ditolak dan hipotesis alternatif $(\mathrm{Ha})$ diterima yang berbunyi "ada pengaruh simultan yang Signifikan dan Positif kepemimpinan transformasional, kepuasan kerja dan motivasi kerja terhadap kinerja pegawai Bank NTB Syariah Kantor Cabang Bima".

\section{PEMBAHASAN}

\section{Pengaruh Parsial Kepemimpinan Transformasional Terhadap Kinerja Pegawai}

Hasil penelitian kepemimpinan Bank NTB Syariah Cabang Bima, mulai dari tingkat Branch Manager, Deputi Branch Manager sampai ke tingkat penyelia tergolong sangat baik yang menunjukkan bahwa pemimpin di Bank NTB Syariah Cabang Bima cenderung memberitahu bawahan apa yang dia harapkan, menetapkan standar kinerja, dan mengontrol perilaku ketika standar kinerja tidak terpenuhi. Pemimpin secara bijaksana memberikan penghargaan dan sanksi disiplin. Bawahan diharapkan mengikuti aturan kebijakan yang dikeluarkan. memperlakukan bawahan dengan sejajar, mengayomi bawahan, dan menampilkan perhatian pribadi terhadap kebutuhan, dan kesejahteraan mereka. Pemimpin yang partisipatif selalu berkonsultasi dengan bawahan, dan menggunakan ide atau saran bawahan sebagai pertimbangan dalam pengambilan keputusan, dan berkonsultasi dengan bawahan tentang bagaimana cara menyelesaikan tugas. Pemimpin yang berorientasi pencapaian akan membuat target yang menantang, mengharapkan bawahan bekerja dalam level tertinggi, dan terus menerus mencari peningkatan kinerja bawahan. Pemimpin percaya bahwa bawahan cukup bertanggung jawab untuk mencapai tujuan yang menantang.

Gaya kepemimpinan yang proposional terhadap keadaan dan lingkungan kerja dapat meningkatkan kinerja bawahan. Hasil pengujian hipotesis penelitian bahwa kepemimpinan transfomasional memiliki pengaruh signifikan terhadap kinerja. Hasil penelitian ini mendukung penelitian Alfiah (2013) bahwa kepemipinan memiliki pengaruh besar terhadap kinerja bawahan. Sukandi dan Toberico (2016) menyimpulkan kepemimpinan berpengaruh signifikan Terhadap Kenerja Pegawai. Berdasarkan dari hasil pengamatan dan wawancara di lapangan, Kepemimpinan transformasional yang ada di Bank NTB Syariah Cabang Bima terlihat seluruh pegawai selalu mengikuti apel pagi 
yang diadakan 3 (tiga) kali dalam seminggu, dimana apel pagi sangat penting untuk meningkatkan disiplin pegawai karena dalam apel pagi pemimpin Branch Manager atau Deputy Branch Manager bersama penyelia saling memberikan informasi, arahan dan motivasi terhadap seluruh pegawai di Bank NTB Syariah Kantor Cabang Bima, selain itu pemimpin berdiskusi bersama meminta masukan saran yang positif untuk mencapai target kinerja yang telah ditetapkan sehingga tujuan perusahaan dapat tercapai. Selain itu seluruh pegawai taat terhadap ketentuan SOP (Standard Operasional Prosedur) yang telah ditetapkan.

\section{Pengaruh Parsial Kepuasan Kerja Terhadap Kinerja Pegawai}

Hasil analisis deskriptif menunjukkan bahwa pegawai Bank NTB Syariah Kantor Cabang Bima memiliki tingkat kepuasan yang tinggi terhadap rekan kerja, budaya kerja dan atasannya mereka. Tingginya kepuasan kerja ini mencerminkan otonomi dan kebebasan, karir benefit, kesempatan untuk maju, kesempatan pengembangan karir, kompensasi/gaji, komunikasi antara karyawan dan manajemen, kontribusi pekerjaan terhadap sasaran organisasi, perasaan aman di lingkungan kerja, kefleksibelan untuk menyeimbangkan kehidupan dan persoalan kerja, keamanan pekerjaan, training spesifik pekerjaan, pengakuan manajemen terhadap kinerja karyawan, keberartian pekerjaan, jejaring, kesempatan untuk menggunakan kemampuan atau keahlian, komitmen organisasi untuk pengembangan, budaya perusahaan secara keseluruhan, hubungan sesama karyawan, hubungan dengan atasan langsung, pekerjaan itu sendiri, keberagaman pekerjaan Robbins dan Judge (2015).

Hasil pengujian hipotesis penelitian ada pengaruh positif dan signifikan kepuasan kerja terhadap kinerja pegawai. Hasil penelitian mendukung penelitian Pariaribo (2014) bahwa kepuasan kerja berpengaruh signifikan kinerja pegawai. Hasibuan (2010:102) menggungkapkan terdapat hubungan timbal balik antara kepuasan kerja dengan kinerja karyawan. Berdasarkan dari hasil pengamatan dan wawancara di lapangan, kepuasan kerja terlihat dimana setiap pegawai diberikan kesempatan yang sama dalam mengembangkan karir dengan diadakannya pelatihan yang dapat meningkatkan kemampuan dan kompetensi pegawai. Selain itu tingginya hubungan harmonis antar pegawai dan saling menghargai serta menghormati antar pegawai baik antar bawahan maupun atasan. Suasana lingkungan kantor yang bersih, aman dan nyaman membuat tingginya kepuasan kerja di kantor Bank NTB Syariah Cabang Bima.

\section{Pengaruh Parsial Motivasi Kerja Terhadap Kinerja Pegawai}

Hasil penelitian menunjukkan bahwa motivasi pegawai Bank NTB Syariah Kantor Cabang Bima tergolong sangat tinggi artinya pegawai memiliki semangat dan daya saing kerja yang sesuai dengan harapan dan standar kerja bank. Kemudian hasil pengujian hipotesis penelitian motivasi kerja memiliki pengaruh signifikan terhadap kinerja. Hasil penelitian mendukung pendapat Latief (2012) mengemukakan bahwa dengan terbentuknya motivasi yang kuat, maka dapat membuahkan hasil atau kinerja yang baik sekaligus berkualitas dari pekerjaan yang telah dilakukan. Setiap peningkatan motivasi yang dimiliki oleh seseorang akan memberikan peningkatan terhadap kinerjanya. Oleh karena itu motivasi kerja yang tinggi diperlukan organisasi untuk meningkatkan kinerja karyawannya.

Menurut Munandar (2011:93), aspek tanggung jawab dalam melakukan pekerjaan adalah kesadaran dalam diri individu dalam melaksanakan kewajiban atau pekerjaan, diiringi rasa keberanian menerima segala resiko, inisiatif yang besar dalam menghadapi kesulitan terhadap pekerjaan dan dorongan yang besar untuk berbuat dan menyelesaikan apa yang segera atau harus diselesaikan. Artinya, seorang karyawan merasa dituntut untuk selalu menyelesaikan pekerjaan yang segera atau harus diselesaikan tepat pada waktunya dan bersedia untuk bekerja melebihi waktu kerjanya dikarenakan 
pekerjaan yang menumpuk, dan setiap menyelesaikan pekerjaan mereka akan fokus terhadap pekerjaan tersebut dan tidak melakukan aktivitas lainnya seperti berbincang dengan rekan kerja karena karyawan memiliki rasa tanggung jawab tinggi terhadap pekerjaan yang dilakukan.

Hasil penelitian ini mendukung penelitian Erman (2013) dan Pariaribo (2014) bahwa seseorang yang memiliki motivasi kerja yang tinggi akan melakukan segala tugas-tugas dengan sebaik-baiknya sehingga memungkinkan akan memiliki kinerja yang lebih produktif dibandingkan dengan pegawai yang rendah motivasinya. Berdasarkan dari hasil pengamatan dan wawancara di lapangan, tingginya motivasi pegawai terlihat dari tingginya tingkat kedisiplinan pegawai yang hadir mengikuti apel pagi yang diadakan setiap 3 (tiga) kali seminggu, dimana apel pagi sangat penting karena dalam apel pagi pemimpin Branch Manager atau Deputy Branch Manager bersama penyelia saling memberikan informasi, arahan dan motivasi terhadap seluruh pegawai di Bank NTB Syariah Kantor Cabang Bima, selain itu pemimpin berdiskusi bersama meminta masukan saran yang positif untuk mencapai target kinerja yang telah ditetapkan sehingga tujuan perusahaan dapat tercapai, hal ini terlihat dari tercapainya target pada seluruh bagian sales funding yaitu lebih dari 15 orang nasabah perbulan, dimana untuk produk tabungan diatas Rp. 250.000.000,-, Deposito diatas Rp.1 M dan Giro diatas Rp. 2 M. Untuk pegawai pada bagian Teller dan Customer Service, tingginya motivasi kerja sehingga berdampak pada minimnya keluhan dari nasabah terhadap pelayanan yang diberikan, sementara pada bagian administrasi tingginya motivasi kerja pegawai berdampak pada teraturnya tata kelola dan tertibnya administrasi pembukuan bank. Tingginya motivasi kerja pegawai di Bank NTB Syariah Kantor Cabang Bima terpacu dengan adanya rencana kenaikan bonus dan kenaikan gaji dengan jenjang karir yang menjanjikan untuk kehidupan yang lebih baik yang akan mereka dapatkan.

Jurnal Ilmu Sosial dan Pendidikan
Pengaruh Simultan Kepemimpinan
Transformasional, Kepuasan Kerja dan
Motivasi Kerja Terhadap Kinerja Pegawai Penelitian awal mengenai kepemimpinan lebih terfokus pada sifat (trait) dan karakteristik pemimpin dalam upaya untuk mengidentifikasi pemimpin yang sukses. Peneliti kepemimpinan mengembangkan tes kepribadian dan membandingkan hasil terhadap mereka yang dianggap pemimpin. Pendekatan ini, menimbulkan berbagai kritik karena hanya mengidentifikasi sifat-sifat yang tidak dapat diprediksi dalam kondisi yang sangat situasional, karena pemimpin tidak hanya menjadi penentu, tetapi juga harus fleksibel dan inklusif terhadap perubahan yang terjadi (Tavfelin, 2013:9).

Artinya keberadaan pemimpin menjadi penentu maju mundurnya suatu organisasi yang dipimpinan karena pemimpin yang baik bagi bahwanya akan meningkatkan tingkat kepuasan pegawai. Menurut Sinambela (2012:258) kepuasan kerja adalah perasaan seseorang terhadap pekerjaannya yang dihasilkan oleh usahanya sendiri (internal) dan yang didukung oleh hal-hal yang dari luar dirinya (eksternal), atas keadaan kerja, hasil kerja, dan kerja itu sendiri. Dengan demikilikinya kepuasan kerja maka akan meningkatkan semangat atau motivasi kerja. Motivasi adalah keinginan dalam diri seseorang yang merangsang ia melakukan tindakan. Derajat atau keadaan rangsangan tersebut tergantung pada pengharapan pribadi terhadap suatu tingkat kepuasan perasaan yang bisa dicapai. Motivasi merupakan dorongan yang ada di dalam diri manusia yang menyebabkannya melakukan sesuatu atau berbuat sesuatu. yang pada gilirannya dapat meningkatkan produktivitas kerja.

Penjelasan tersebut di atas mengindikasikan bahwa kepemimpinan, kepuasan kerja dan motivasi secara simultan memiliki pengaruh terhadap kinerja pegawai Bank NTB Syariah Cabang Bima. Hasil penelitian mendukung penelitian yang dilakukan oleh Kashif Rathore dan Chaudhry Abdul Khaliq (2017), Erman (2013) dan Elqadri, Wardoyo dan Priyono (2015) bahwa 
secara bersama-sama kinerja pegawai/karyawan dipengaruhi oleh model kepemimpinan yang partisipatif, kepuasan kerja yang memungkin karyawan bekerja dengan otonom dan motivasi kerja pegawai dalam menjalankan tugas dan tanggung jawab sebagai pegawai pada kantor perbankan. Oleh karena itu dalam meningkatkan kualitas kerja pegawai maka harus memperhatikan secara bersama-sama tentang gaya kepemimpinan yang proposional terhadap fungsi-fungsi menajemen, kepuasan kerja dan motivasi kerja pegawai yang dapat dilakukan dengan berbaik cara termasuk dalam kebijakan promosi dan kompensasi yang membuat bawahan semakin semangat dalam bekerja.

\section{Implikasi Hasil Penelitian}

Dari penelitian ini terlihat ada temuan yaitu bahwa keberadaan variabel motivasi kerja menjadi variabel yang paling dominan dan penentu dalam meningkatkan kinerja pegawai menuju organisasi perbankan syariah yang berdaya sanding dan saing dengan perbankan konvesional. Namun demikian motivasi pegawai ini harus diidukung oleh adanya kepuasan kerja pegawai terhadap lingkungan pekerjaan, budaya komunikasi, interaksi dan gaya kepemimpinan transformasional. Temuan penelitian ini mendukung pentingnya teori kepuasan Herzberg dan Spancer dan Spancer didalam peningkatan kinerja dalam bidang Manajemen Sumber Daya Manusia (MSDM) pada suatu organisasi baik organisasi swasta maupun organisasi pemerintah. Oleh karena itu, dapat direkomendasikan dari hasil penelitian bahwa peningkatan kinerja pegawai dalam konsep pelaksanaan teori Manajemen Sumber Daya Manusia (MSDM) tidak hanya dapat dijabarkan oleh variable yang telah digunakan pada penelitian ini. Namun demikian sudah membatu Bank NTB Syariah Kantor Cabang Bima dalam pengembangan SDM pegawai yang professional dengan yang berdaya saing, tentunya pegawai yang memiliki kompetensi, keterampilan kerja tinggi dan bertanggung jawab serta sebagai icon atau model pegawai pada bank syariah yang layak untuk tiru oleh pegawai organisasi lain.

Jurnal Ilmu Sosial dan Pendidikan

\section{KESIMPULAN}

Dari hasil analisis data penelitian dan pembahasan maka kesimpulan penelitian yaitu:

1. Kepemimpinan Transformasional memiliki pengaruh yang signifikan dan positif terhadap kinerja pegawai Bank NTB Syariah Cabang Bima, karena gaya kepemimpinan transformasional menunjukkan kemampuan dalam mengkoordinir pegawai dalam menghasilkan kinerja organisasi secara keseluruhan.

2. Kepuasan kerja memiliki pengaruh signifikan dan positif terhadap kinerja pegawai Bank NTB Syariah Cabang Bima, pegawai yang memiliki kepuasan kerja terhadap pekerjaan maka akan dapat menggerakan dirinya untuk melakukan suatu pekerja dengan penuh tanggung jawab.

3. Motivasi kerja memiliki pengaruh signifikan dan positif terhadap kinerja pegawai Bank NTB Syariah Cabang Bima karena pegawai yang motivasi kerja yang tinggi akan berdampak pada keuletan dan ketelitian kerja, dimana kinerja pegawai merupakan dampak dari kesungguhan dan keuletan yang bersifat kontinuitas.

4. Kepemimpinan, kepuasan kerja dan motivasi kerja secara simultan berpengaruh signifikan terhadap kinerja pegawai, karena atasan yang memiliki gaya kepemimpinan yang tegas dan fleksibel akan mampu memotivasi pegawai untuk bekerja sehingga melahirkan kepuasan kerja tersendiri bagi pegawai sebagai bawahannya.

Berdasarkan kesimpulan penelitian ada beberapa hal penting sebagai saran penelitian, yaitu:

1. Peningkatan motivasi kerja, kepuasan kerja dan pemilihan gaya kepemimpinan di Bank NTB Syariah Kantor Cabang Bima harus dilakukan secara keseluruhan dari beberapa variabel penelitian. Ini dapat dilakukan dengan adanya pemberian insentif, pelatihan dan pengembangan karir secara berkala serta adanya 
regregenerasi dan kaderisasi dalam kepemimpinan.

2. Pemimpin di Bank NTB Kantor Cabang Bima hendaklah memperhatikan kepuasan kerja dan motivasi kerja bawahannya karena berdasarkan hasil penelitian memiliki pengaruh signifikan terhadap kinerja pegawai. Oleh karena itu bagi pimpinan agar memiliki gaya kepemimpinan yang mendukung dan menyesuikan diri dengan tuntutan kerja, karakteristik pegawai agar terjalin hamonisasi dalam setiap menyelesaikan tugas.

3. Penelitian yang melakukan kajian penelitian serupa agar melakukan telaah akademik secara mendalam mengenai faktor-faktor yang mempengaruhi kinerja, kepuasan kerja dan motivasi kerja yang ditinjau dari gaya kepemimpinan lain karena berdasarkan hasil penelitian semakin tinggi kepuasan kerja, motivasi kerja dan kepuasan kerja maka akan semakin tinggi kinerja pegawai.

\section{DAFTAR PUSTAKA}

Abidin, Z., \& Endri. (2010). Kinerja Efisiensi Teknis Bank Pembangunan Daerah: Pendekatan Data Envelopment Analysis (DEA). Jurnal Akuntansi dan Keuangan, Vol. 11, No. 1.

Agung, G.L., (2013). Pengaruh Motivasi, Kepuasan, Dan Sikap Kerja Terhadap Kinerja Karyawan Di Café X Bogor. Journal Binus Business Review Vol. 4 No. 2 November 2013: 596-606. https://media.neliti.com/media/publica tions/167877-ID-pengaruh-motivasikepuasan-dan-sikap-ker.pdf.

Anoraga, P. (2009). Psikologi Kerja. Jakarta: Rineka Cipta

Arif,Y.S. (2016). Pemahaman Manajemen sumber daya manusia. Yokyakarta: CAPS (Canter for Academic Publishing Service).

Arikunto, S. (2012). Prosedur Penelitian. Jakarta: Rineka Cipta.

Angelo, M.S. (2011). Islamic Banking and Finance In South-East Asia Its
Development and Future. Singapura: World Scientific Publishing.

Anshori, A.G. (2012). Perbankan Syariah di Indonsia. Yogyakarta: Gajah Mada University Press.

Avilla, G. (2017). Gaya Kepemimpinan Transformasional, Keadilan Organisasi, dan Reaksi Karyawan Terhadap Kinerja Karyawan. Jurnal Manajemen dan Pemasaran Jasa Vol. 10 No. 1 Maret 2017 : 129-140 Doi: http://dx.doi.org/10.25105/jmpj.v10i1. $\underline{1670 .}$.

Bank NTB Syariah. (2018). Sejarah Bank NTB Syariah. https://www.bankntbsyariah.co.id/Per usahaan/tentangBankNTBSyariah/seja rah-bank-ntb-syarah. Diakses Tanggal 20 April 2019.

Bass, B.M. (2011), "Does the Transactionaltransformational Leadership Paradigm Transcend Organisational and National Boundaries", American Psychologist, Vol. 52 No.2, pp.130-9.

Basit, B. \& Sebastian, S. (2017). Impact Of Leadership Style On Employee Performance (A Case Study On A Private Organization In Malaysia). International Journal of Accounting \&Business Management Vol. 5 (No.2), November, 2017

Bass, B. M., \& Riggio, R. E. (2006). Transformational leadership (2nd ed.). Mahwah, NJ: Erlbaum.

Cheok, E.R.E., \& O'Higgins. (2012) "Enhancing employee outcomes: The interrelated influences of managers' emotional intelligence and leadership style", Leadership \& Organization. Development Journal, Vol. 33 Iss: 2, pp.149- 174

Elqadri \& Priyono. (2015). The Influence of Motivation and Discipline Work against Employee Work Productivity Tona'an Markets. Review of European Studies; Vol. 7, No. 12; 2015 ISSN 1918-7173 E-ISSN 1918-7181 Published by Canadian Center of Science and Education. 
Erman. (2013). Pengaru Pelatihan, Budaya Organisasi, Mtoivasi Dan Efektifitas Kerja Terhadap Kinerja Pegawai Bandan Kesatuan Bangsa, Politik dan Pelindungan Masyarakat Kediri.

Fahmi, I. (2012). Percepatan Pertumbuhan Perbankan Syariah. Program Pascasarjana Manajemen dan Bisnis IPB. 1-2

Ghozali, I. (2012). Aplikasi Analisis Multivariate Dengan Program SPSS. Semarang: Badan Penerbit Universitas Diponegoro.

Handoko \& Supriyono. (2011). Manajemen Personalia dan Sumber daya Manusia, Edisi Kedua. Yogyakarta: BPFE.

Hughes, R. L., Ginnet, R. C., \& Curphy, G. L. (2006). Leadership: Enhancingthe Lesson Of Experience (5th Ed.). New York: McGraw-Hill.

Hasibuan, S.P. (2011). Manajemen Sumber Daya Manusia. Cetakan ke-11. Jakarta: PT.Bumi Aksara.

Iqbal N., Anwar S., \& Haider, N. (2015). Effect of Leadership Style on Employee Performance. Arabian Journal Bus Manag Review 5: 146. doi:10.4172/2223-5833.1000146

Ivancevich, J.M., \& Konopaske, R. (2010). Perilaku dan Manajemen Organisasi, Penerjemah Gania Gina. Edisi Ketujuh. Jakarta: Penerbit Erlangga.

Kashif, R., \& Chaudhry, A.K.. (2017). The Influence of Leadership Styles on Employees Performance under Perceptions of Organizational Politics: A Study of Telecom Sector in Pakistan. International Journal of Management Research and Emerging Volume 7 Issue 1 (2017) PP. 106-140.

Kompas. (2012). Tiga Masalah Terbesar Bank Syariah di Indonesia. https://money.kompas.com/read/2012/ 08/13/15282835/Tiga.

Masalah.Terbesar.di.Bank.Syariah.

Republika. (2019). Bank NTB Syariah Gagal Salurkan KUR https://republika.co.id/berita/pyzusv38 3/bank-ntb-syariah-gagal-salurkan-kur
Latief, B. (2012). Faktor- faktor yang Mempengaruhi Kinerja Karyawan PT. Mega Mulia Servindo di Makasar. Jurnal Manajemen dan Akuntansi , 1 (1), 61- 70 .

Lubis, S.H.,. (2016). Aspek-aspek Etos Kerja dan Faktor-faktor yang Mempengaruhinya. (http://www.SatriaHadiLubis/aspekaspek-etos-kerja-dan -faktor-faktoryang-mempengaruhi.

Mansyur, F. (2012). Analisis Perbandingan Efisiensi Bank Umum Konvensional (BUK) dan Bank Umum Syariah (BUS) di Indonesia dengan Metode Stochastic Frontier Approach (SFA) (Periode 2009-2011). UIN Sunan Kalijaga, Yogyakarta.

Marimin \& Romdhoni. (2015). Perkembangan Bank Syariah di Indonesia. Jurnal Ilmiah Ekonomi Islam - Vol. 01, No. 02, Juli 2015.

Mangkunegara. (2010). Manajemen Sumber Daya Manusia Perusahaan. Bandung: Remaja Rosdakarya.

Mahsun, M., Sulistiyowati, F., \& Purwanugraha, H.A. (2011). Akuntansi Sektor Publik. Edisi Ketiga. Yogyakarta. BPFE.

Mahsun, M., Sulistiyowati, F., Purwanugraha, H.A. (2011).Akuntansi Sektor Publik. Edisi Ketiga. Yogyakarta. BPFE.

Munandar, A. S. (2011). Psikologi Industri. Jakarta: CV. Kurnia.

Nur, A. (2013). Pengaruh Kepuasan, Motivasi dan Kedisiplinan Kerja Terhadap Kinerja Pegawai Di Lingkungan Kantor Wilayah Departemen Agama Provinsi Jawa Tengah. Tesis Program Pascasarjana Universitas Dian Nuswantoro Semarang.

http://eprints.dinus.ac.id/15056/1/JURNAL_T ESIS.pdf. Diakses 26 Okbtober 2019.

Tafvelin \& Susanne. (2013). The Transformational Leadership Process Antecedents, Mechanisms, and Outcomes in the Social Services. Sweden: Print and Media Umea. 
Thoha, M. (2012). Perilaku Organisasi Konsep Dasar dan Aplikasinya. Jakarta: PT. Rajagrafindo Persada.

Rivai \& Sagala. (2010). Manajemen Sumber Daya Manusia untuk Perusahaan: dari Teori ke Praktik. Jakarta: Raja Grafindo Persada.

Ridwan, M. (2012). Perencanaan dan Pengembangan Pariwisata. PT Sofmedia: Medan.

Robbins, S. \& Mary Coulter. (2010). Manajemen. Edisi Kesepuluh. Alih Bahasa Bob Sabran dan Devri Bernadri Putra. Jakarata: Erlangga.

Robbins, S.\& Timothy. (2010). Perilaku Organisasi. Jakarta: Salemba Empat. Edisi ke16.

Pariaribo, N. (2014.) Pengaruh Gaya Kepemimpinan dan Motivasi Kerja Terhadap Kepuasan Kerja Serta Dampaknya Terhadap Kinerja Pegawai Pada Badan Perencanaan Pembangunan Daerah di Kabupaten Supiori, Universitas Atma Jaya: Yogyakarta.

Santoso \& Singgih. (2013). Buku Latihan SPSS Statistik Parametrik. Jakarta: Elex Media Komputindo.

Sukandi \& Toberico. (2016). Pengaruh Gaya Kepemimpinan Terhadap Kinerja pegawai (Studi Kasus Gaya Kepemimpinan Situasional di Kantor Pelayanan Pajak Pratama Bandung Cibeunying. Conference on Management and Behavioral Studies Universitas Tarumanagara, Jakarta, 27 Oktober 2016 ISSN NO: 2541-3400 eISSN NO: 2541-2850.

Suryani. (2012). Sistem Perbankan Islam di Indonesia: Sejarah dan Prospek Pengembangan. Jurnal Muqtasid Volume 3 Nomor 1, Juli 2012.

Sunarto. (2013). Manajemen Sumber Daya Manusia Strategik. Yogyakarta: AMUS.

Suprayitno. (2017). Pengaruh Disiplin Kerja, Lingkungan Kerja dan Motivasi Kerja Terhadap Kinerja Karyawan. Jurnal Sumber Daya Manusia UB.
Sugiyono. (2014). Metode Penelitian Kuantitatif Kualitatif dan $R$ \& $D$. Bandung : Alfabeta.

Wanda F. (2015). Pengaruh Kepuasan Kerja Terhadap Kinerja Karyawan Pt. Kabepe Chakra 2015. e-Proceeding of Management: Vol. 2, No. 3 Desember $2015 \quad$ Page 2954. file:///D:/Downloads/15.04.2123_jurn al_eproc.pdf.

Widoyoko, P. (2012. Evaluasi Program Pembelajaran. Yogyakarta: Pustaka belajar.

Yukl. G. (2010). Kepemimpinan Dalam Organisasi. Terjemahan Budi Supriyanto. Jakarta: Indeks.

Zafer. (2012). Organizational Culture, Leadership Style and Organization Commitment in Turkish Logistics Industry. Journal of Occupational Psychology, 63, 1-18. 